\title{
ANALISA FAKTOR PEMILIHAN MODA TRANSPORTASI MENGGUNAKAN METODE ANALYTIC HIERARCHY PROCESS
}

\author{
Sugiyanto, I Wayan Arnaya, Stefanus Sylvan Ryanto, A.A.Bagus Oka Khrisna Surya* \\ Manajemen Transportasi Jalan, Politeknik Transportasi Darat Bali, Jl. Cempaka Putih, Desa Samsam, \\ Kec.Kerambitan, Kab. Tabanan - Bali, Indonesia 80582 \\ *oka@poltradabali.ac.id
}

\begin{abstract}
ABSTRAK
Ketersediaan transportasi darat khususnya kendaraan pribadi di Bali terus menunjukan peningkatan seiring dengan perputaran roda perekonomian, ketersediaan transprortasi selain memberikan dampak positif bagi pertumbuhan ekonomi dan pariwisata di Bali juga memberikan dampak negatif salah satunya adalah kemacetan. Program Bus Trans Sarbagita sebagai salah satu bentuk transportasi masal hadir untuk menjawab persoalan kemacetan di Bali malah kurang mendapat sambutan yang baik untuk itu perlu diketahui faktor - faktor apa saja yang mempengaruhi minat masyarakat Bali dalam memilih moda transportasi antara kendaraan pribadi dan transportasi masal agar dapat meningkatkan minat masyrakat Bali untuk menggunakan moda transportasi masal secara efektif.. Penelitian ini bertujuan untuk mengetahui faktor - faktor yang mempengaruhi pelaku perjalanan dalam pemilihan moda antara transportasi masal dan kendaraan pribadi menggunakan Analytic Hierarchy Process (AHP) dengan studi exploratif dengan responden pengguna moda yang dipandang sebagai expert dalam sudut pandang pemilihan moda transportasi.Hasil analisis diperoleh bahwa keselamatan $(28,3 \%)$ menjadi faktor utama dalam pemilihan moda transportasi yang diikuti oleh faktor keamanan $(23,3 \%)$, kehandalan (12,3\%), kenyamanan (11,7\%), kebersihan (10,2\%), aksesibilitas $(8,4 \%)$, dan biaya $(5,8 \%)$ untuk solusi kendaraan pribadi $(74.4 \%)$ menjadi moda transportasi teroilih dibandimgkan dengan kendaraan umum (25.6\%.) berdasarkan faktor - faktor tersebut.
\end{abstract}

Kata Kunci: AHP; moda transportasi; pemilihan alternatif

\section{TRANSPORTATION MODE SELECTION FACTOR ANALYSIS USING ANALYTIC HIERARCHY PROCESS METHOD}

\begin{abstract}
The availability of land transportation in Bali, especially the private vehicles, continues to show an increase along with economic growth, the availability of transportation, apart from having a positive impact on economic growth and tourism in Bali, also has a negative impact like congestion. The Trans Sarbagita Bus Program as one form of mass transportation is appear to answer the problem of congestion in Bali, instead it has not received a good response. Therefore, it is necessary to know what factors influence the interest of the Balinese people in choosing the mode of transportation between private vehicles and mass transportation in order to increase the interest of the Balinese people to use mass transportation modes effectively. This study aims to determine the factors that influence travelers in the choice of mode between mass transportation and private vehicles using the Analytic Hierarchy Process (AHP) with an exploratory study using mode transportation user as respondent who are seen as experts in the perspective of choosing the mode of transportation. The analysis, it was found that safety $(28.3 \%)$ was the main factor in choosing the mode of transportation followed by security (23.3\%), reliability (12.3\%), comfort (11.7\%), cleanliness $(10.2 \%)$, accessibility $(8.4 \%)$, and costs (5.8\%) for the solutions private vehicles $(74.4 \%)$ being the preferred mode of transportation compared to public transportation (25.6\%.) based on those factors.
\end{abstract}

Keywords: Alternative Selection, Mode of Transportation, AHP 


\section{PENDAHULUAN}

Transportasi erat kaitannya dengan perkembangan industri pariwisata sebagai sarana penunjang aksesibilitas dalam menjangkau daerah objek tujuan wisata, menurut Sudiarta (2005) akses transportasi dapat meningkatkan perkembangan wisata serta peningkatan jumlah wisatawan. Sebagai destinasi tujuan wisata baik wisatawan domestik maupun mancanegara, menjadikan Bali mengandalkan sektor wisata dan transportasi sebagai tulang punggung ekonomi, hal ini terlihat dari kontribusi 2 sektor tersebut sebagi kontributor tertinggi bagi PDRB Bali sebesar 33.12\% di tahun 2019 (BPS, 2019).

Ketersediaan transportasi khususnya transportasi darat terus menunjukan peningkatan seiring dengan perputaran roda perekonomian, pada periode 2013 - 2017 terjadi peningkatan jumlah kendaraan bermotor yang cukup tinggi yaitu sebesar $7.40 \%$ per tahunnya (BPS, 2018). Ketersediaan transprortasi selain memberikan dampak positif bagi pertumbuhan ekonomi dan pariwisata di Bali juga memberikan dampak negatif salah satunya adalah kemacetan. Sebagaimana dialami oleh beberapa kota besar di Indonesia, Bali pun tidak luput dari persoalan kemacetan. Aglomerasi kawasan yang teramat pesat di Bali telah menjadikan kawasan Bali amat padat, sehingga kemacetan pun tidak dapat dihindarkan. Hal ini menjadi ironi tersendiri tersendiri mengingat bebas dari kemacetan merupakan salah satu syarat untuk mewujudkan destinasi pariwisata yang ideal.

Pemerintah Provinis Bali tidak tinggal diam dan berupaya mengatasi kemacetan tersebut, salah satunya mewujudkan program transportasi publik masal berbasis Bus (Trans Sarbagita). Program Bus Trans Sarbagita menjadi salah satu program yang diharapkan mampu menggiring masyarakat beralih menggunakan transportasi publik, program ini hadir selain untuk menjawab persoalan kemacetan di Bali juga sebagai respon pemerintah Provinsi Bali terhadap minimnya jumlah transportasi publik di Bali, yang mana jumlah angkutan umum di Pulau Dewata hanya 3\% dari keseluruhan transportasi yang ada, padahal idealnya, proporsi angkutan umum harus lebih besar dibandingkan angkutan lainnya yakni dengan jumlah 70\% dari total keseluruhan kendaraan. Akan tetapi sejak awal beroperasi, program ini sepertinya kurang mendapat sambutan yang baik dari masyarakat di Denpasar dan sekitarnya (Metro Bali, 10 April 2013). Hingga menjelang 3 tahun pengoperasiannya, tingkat keterisian penumpang bus Trans Sarbagita utamanya pada koridor II masih antara 30-40 persen setiap hari (Tribunnews.com, 30 Juni 2014). Minat masyarakat untuk memanfaatkan angkutan ini jauh dari harapan, kendati tarif bus itu tergolong cukup murah.

Berangkat dari hal tersebut diatas, maka penelitian ini bertujuan untuk mengetahui faktor faktor yang mempengaruhi pelaku perjalanan dalam pemilihan moda antara transportasi masal dengan kendaraan pribadi khususnya bagi pelaku perjalanan dari Bandara I Gusti Ngurah Rai ke kota Denpasar. Pengolahan data menggunakan analisa Analytic Hierarchy Process. Dari hasil penelitian ini diharapkan dapat memberikan gambaran kondisi aktual dari faktor penyebab dominan mengapa masyarakat kurang memilih menggunakan transportasi masal sehingga dapat membantu pihak terkait dalam mengambil dan merumuskan kebijakan yang efisien dalam meningkatkan minat masyrakat dalam menggunakan transportasi masal.

\section{METODE}

Tahap pertama, tahap valiadasi dan eksplorasi variabel, dilakukan penyebaran kuisioner awal yang ditujukan pada para pengguna moda transportasi sebagai responden untuk mengetahui relevansi apakah variabel - variabel yang mempengaruhi dalam pemilihan moda transportasi yang telah dirumuskan berdasarkan studi literatur memang relevan dengan kondisi aktual di lapangan, pada tahap ini juga dilakukan waawncara untuk memberikan deskripsi untuk tiap 
variabel yang dianggap relevan oleh masing - masing responden serta untuk mengetahui pendapat tiap responden berkenaan pada alternatif moda apa yang dianggap cocok untuk daerah sasaran penelitian. Tiap responden juga diberikan kewenangan untuk mengurangi atau juga menambahkan variabel berdasarkan pengetahuan dan pengalamannya pada kuisioner awal ini.

Tahap kedua, tahap formulasi hirarki matrik keputusan, dimana responden diminta untuk menilai derajat kepentingan antara tiap variabel yang telah diperoleh pada tahap pertama. Pada thapa ini juga menilai derajat kepentingan tiap variabel jika disandingkan dengan alternatif pilihan moda menggunakan metode pairwise comparissson dengan skala nilai likert. Tahap ketiga, olah data dan validasi menggunakan bantuan software Expert Choice 11, hasil olahan dikatakan valid jika tingkat inkonsistensi jawaban $<10 \%$ yang dilihat dari tingkat Consistency Ratio (CR) gabungan yang dihitung dengan membagi nilai Consistency Index (CI) dengan Random Index (RI) yang nilainya tidak boleh lebih besar dari 10\% agar dapat hasilnya dikatakan valid.

\section{HASIL DAN PEMBAHASAN}

Hasil eksplorasi variabel dengan cara studi literatur dari beberapa jurnal diperoleh 8 faktor yang mempengaruhi seseorang dalam memilih moda transportasi yaitu faktor keselamatan, keamanan, kehandalan, kenyamanan, kebersihan, waktu tempuh, biaya dan aksesibilitas, yang secara lengkap dapat dilihat pada tabel berikut.

Table 1.

Uraian Faktor - faktor yang mempengaruhi alternatif pemilihan moda transportasi

\begin{tabular}{|c|c|c|c|}
\hline No & Faktor & Sumber & Variabel \\
\hline 1 & $\begin{array}{l}\text { Keselamatan } \\
\text { (safety) }\end{array}$ & \begin{tabular}{lll} 
& & \multicolumn{1}{c}{ Suatu Keadaan dimana } \\
Kusumastuti, P. B. kita terlindungi dari \\
$(2013) . \quad$ Analisis & kemungkinan yang \\
faktor pemilihan & menyebabkan timbulnya \\
moda & KRDE & resiko bahaya atau cedera \\
Semarang-Tegal. & (OXFORD \\
& & DICTIONARY)
\end{tabular} & $\begin{array}{l}\text { X1 : Kondisi Pengemudi } \\
\text { X2 : Kelengkapan SIM } \\
\text { X3 : Kondisi Cuaca }\end{array}$ \\
\hline 2 & $\begin{array}{l}\text { Keamanan } \\
\text { (Security) }\end{array}$ & $\begin{array}{lrl}\text { Kusumastuti, P. B. } & \\
(2013) . & \text { Analisis } & \text { Suatu Keadaan kita } \\
\text { terbebas dari Bahaya dan } \\
\text { faktor pemilihan } & \text { Ancaman (OXFORD } \\
\text { moda } & \text { KRDE } & \text { DICTIONARY) } \\
\text { Semarang-Tegal. } & \end{array}$ & 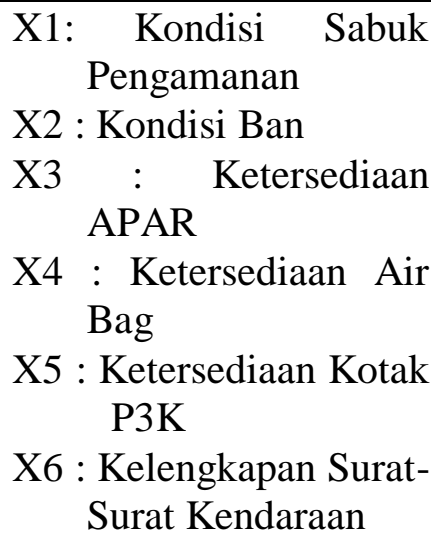 \\
\hline 3 & $\begin{array}{l}\text { Kehandalan } \\
\text { (Reliability) }\end{array}$ & 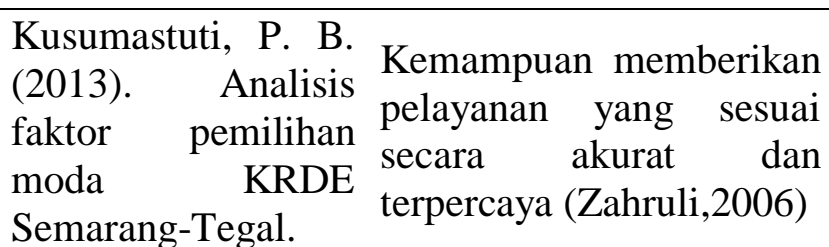 & $\begin{array}{l}\text { X1 : Merek Kendaraan } \\
\text { X2 : Umur Kendaraan } \\
\text { X3 : Tipe Kendaraan }\end{array}$ \\
\hline
\end{tabular}




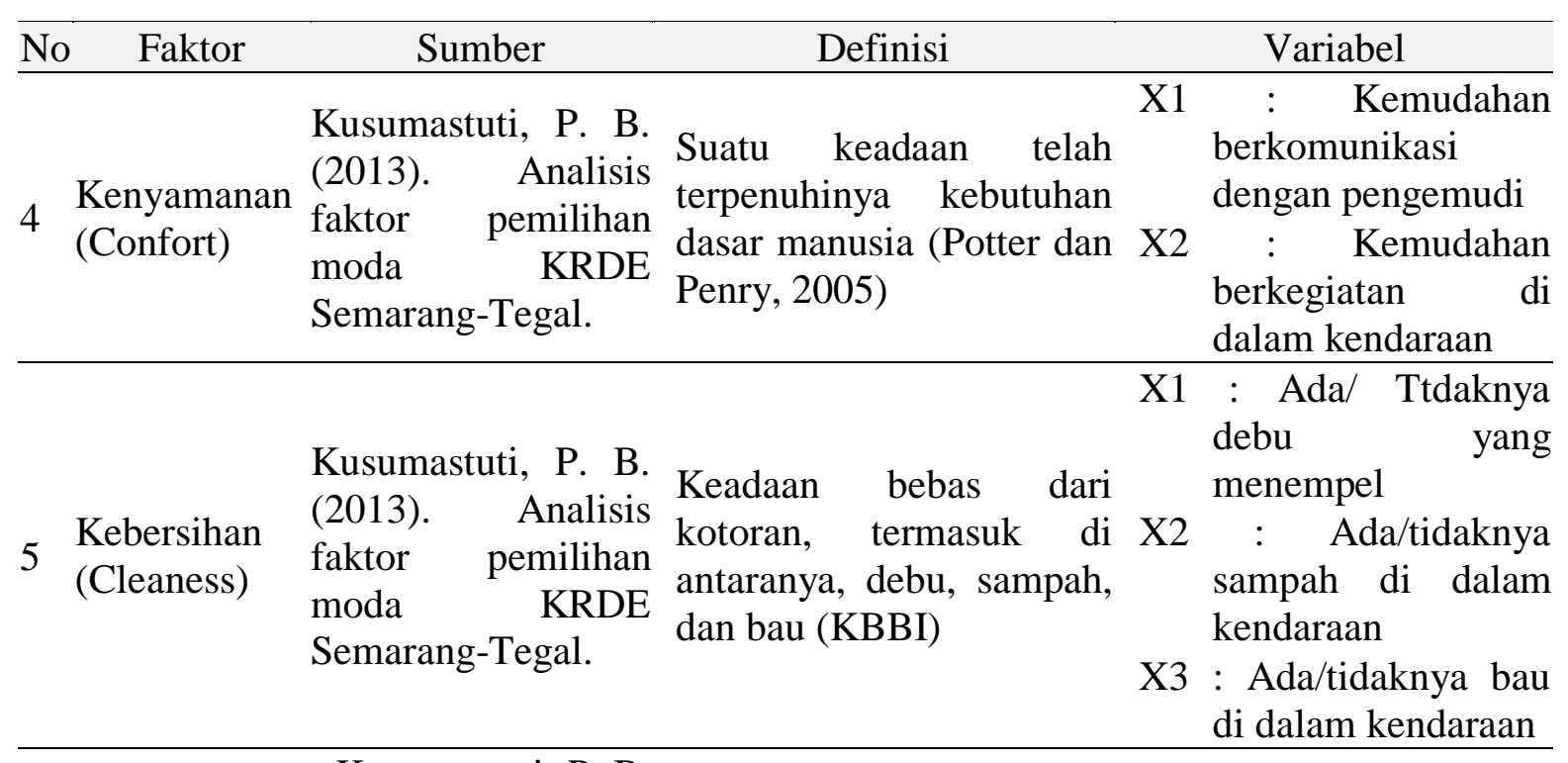

\begin{tabular}{|c|c|c|c|c|}
\hline 6 & $\begin{array}{l}\text { Waktu } \\
\text { Tempuh } \\
\text { (Travel Time) }\end{array}$ & \begin{tabular}{lr}
\multicolumn{3}{l}{ Kusumastuti, P. B. } \\
$(2013)$. & Analisis \\
faktor pemilihan \\
moda $\quad$ KRDE \\
Semarang-Tegal.
\end{tabular} & $\begin{array}{l}\text { Lama perjalanan dari asal } \\
\text { menuju tujuan } \\
\text { (Kusumastuti, 2013) }\end{array}$ & $\begin{array}{l}\text { Jarak dan Waktu } \\
\text { Tempuh Rata Rata }\end{array}$ \\
\hline 7 & Biaya (Cost) & $\begin{array}{l}\text { Saputra, dkk.(2017) } \\
\text { Analisa Faktor - } \\
\text { Faktor Yang } \\
\text { Mempengaruhi } \\
\text { Pemilihan Moda } \\
\text { Menuju Tempat } \\
\text { Kerja } \\
\text { Menggunakan AHP }\end{array}$ & $\begin{array}{l}\text { Besarnya biaya yang } \\
\text { harus } \\
\text { ditanggung/dikeluarkan } \\
\text { untuk perjalanan pulang } \\
\text { pergi (Saputra dkk, 2017) }\end{array}$ & $\begin{array}{l}\text { (Variatif, berbeda antar } \\
\text { responden) }\end{array}$ \\
\hline 8 & $\begin{array}{l}\text { Aksesibilitas } \\
\text { (Accesibility) }\end{array}$ & $\begin{array}{lc}\text { Saputra, dkk.(2017) } \\
\text { Analisa Faktor - } \\
\text { Faktor Yang } \\
\text { Mempengaruhi } \\
\text { Pemilihan Moda } \\
\text { Menuju Tempat } \\
\text { Kerja } \\
\text { Menggunakan AHP }\end{array}$ & $\begin{array}{l} \\
\text { Tingkat Kemudahan } \\
\text { Untuk Mencapai Lokasi } \\
\text { Tujuan (Saputra dkk, } \\
\text { 2017) }\end{array}$ & $\begin{array}{lc}\mathrm{X} 1 & \text { : Kemudahan } \\
\text { mencapai } \\
\text { kendaraan }\end{array}$ \\
\hline
\end{tabular}

Kuisioner disampaikan kepada 107 orang melalui penyebaran kuisioner hand-out dan elektronik (dalam bentuk google form). Metode simple random sampling dilakukan untuk penentuan responden; pemilihan acak orang-orang yang layak menjadi objek penelitian. Berdasarkan hasil penyebaran kuesioner, data demografis yang terkumpul adalah 67 responden laki-laki dan 40 perempuan dengan komposisi usia yang berbeda-beda sebagaimana ditampilkan dalam tabel. 
Tabel 2.

Jumlah Responden Berdasarkan Jenis Kelamin dan Umur

\begin{tabular}{lllllll}
\hline & \multicolumn{2}{l}{ Tingkat Usia } & & & Total \\
\hline & $<18$ & $18-28$ & $29-38$ & $39-48$ & $>48$ & \\
\hline Laki-laki & 2 & 55 & 9 & 1 & 0 & 67 \\
\hline Perempuan & 3 & 34 & 3 & 0 & 0 & 40 \\
\hline Total & 5 & 89 & 12 & 1 & 0 & 107
\end{tabular}

Olah data dilakukan hanya pada 70 orang responden hal ini dikarenakan nilai konsistensi jawaban responden tersebut sama dengan atau dibawah $10 \%(\mathrm{CR} \leq 10 \%)$ sedangkan sisanya diatas 10\%, berikut hasil olah data menggunakan progam Expert Choice 11 dengan nilai CR gabungan sebesar $1 \%$ yang lebih jelasnya dapat dilihat pada gambar berikut :

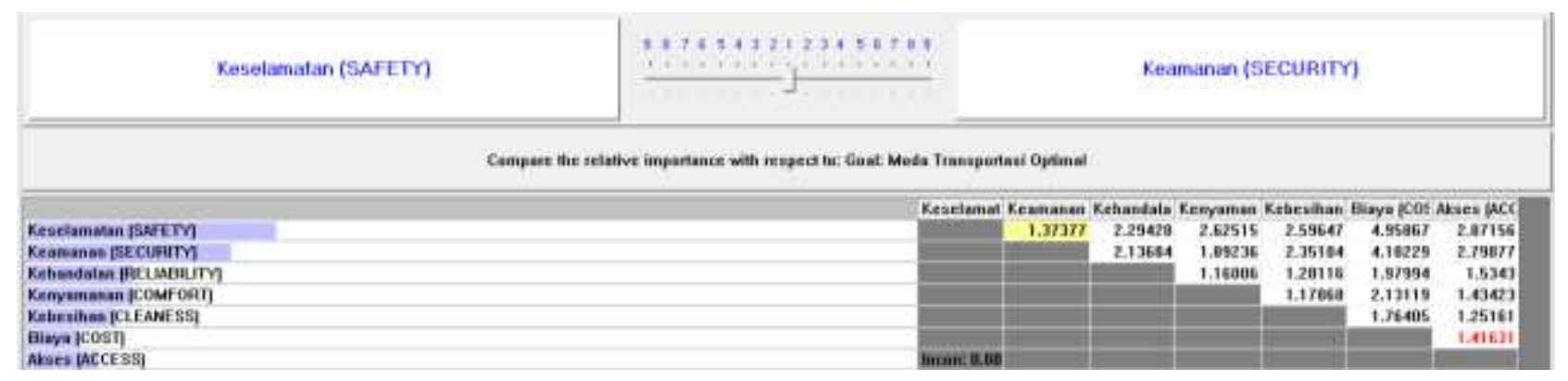

Gambar 1. Tingkat Kepentingan Faktor

Dari hasil olah data diperoleh bahwa keselamatan menjadi faktor terpenting dalam konteks tujuan untuk memilih moda transportasi terbaik dengan nilai sebesar 28.3\%. Nilai bobot kedua yang nilainya cukup dekat dengan keselamatan adalah kemananan (23.3\%). Kehandalan dan kenyamanan masing-masing memiliki nilai $12.3 \%$ dan $11.7 \%$. Sedangkan nilai bobot kebersihan sebesar $10.2 \%$ dan akses sebesar $8.4 \%$ dari total bobot nilai, adapun faktor biaya merupakan faktor yang memiliki prioritas paling rendah dengan nilai tingkat kepentingan sebesar 5.8\%. yang lebih jelasnya dapat dilihat pada tabel berikut :

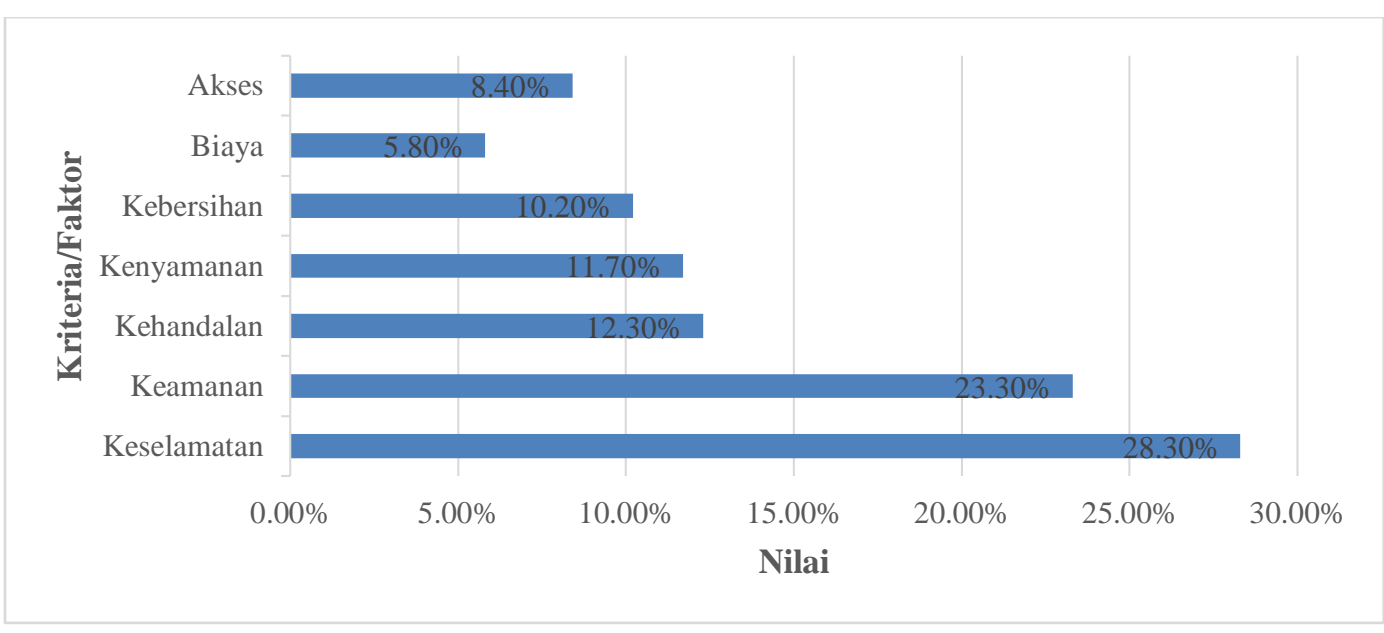

Gambar 2. Hasil penilaian faktor-faktor yang mempengaruhi pemilihan moda transportasi

Sedangakan untuk solusi alternatif moda transportasi antara kendaraan pribadi ( $74.40 \%$ ) dan moda transportasi masal $(25.60 \%)$, mayoritas responden memilih kendaraan pribadi lebih 
baik dibandingkan dengan moda transportasi umum dalam sudut pandang faktor keselamatan, keamanan, kehandalan, kenyamanan, kebersihan, waktu tempuh, biaya dan aksesibilitas.

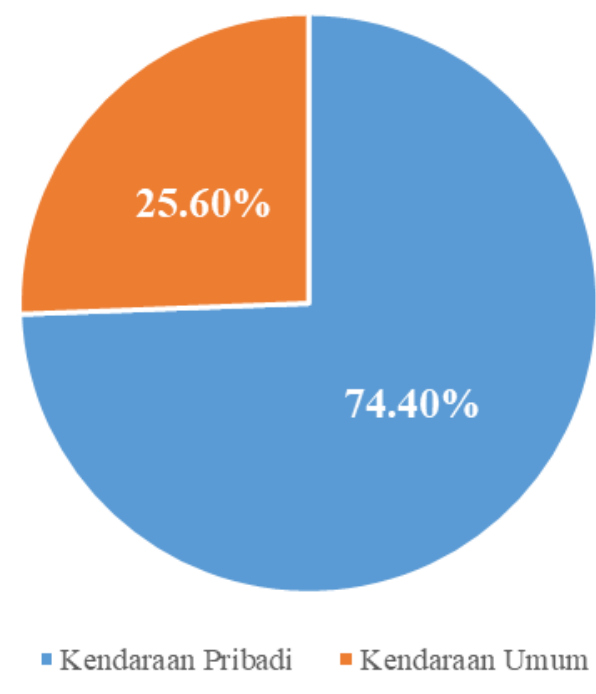

Gambar 3.

Nilai pemilihan moda kendaraan pribadi dan transportasi masal

Dalam upaya melihat berbagai alternatif kriteria untuk melakukan pergeseran jumlah pengguna kendaan pribadi menjadi kendaraan umum, dilakukan simulasi dengan menaikkan nilai dari setiap variabel yang telah ditentukan. Dari ketujuh variabel tersebut hanya variabel biaya yang berpengaruh dalam meningkatkan minat reponden dalam memilih kendaraan umum. Jika variabel biaya tingkat kepentingannya dinaikan hingga $50.2 \%$ dan nilai variable yang lain tetap, maka sebesar $7 \%$ responden mau untuk berpindah menggunakan moda transportasi umum.

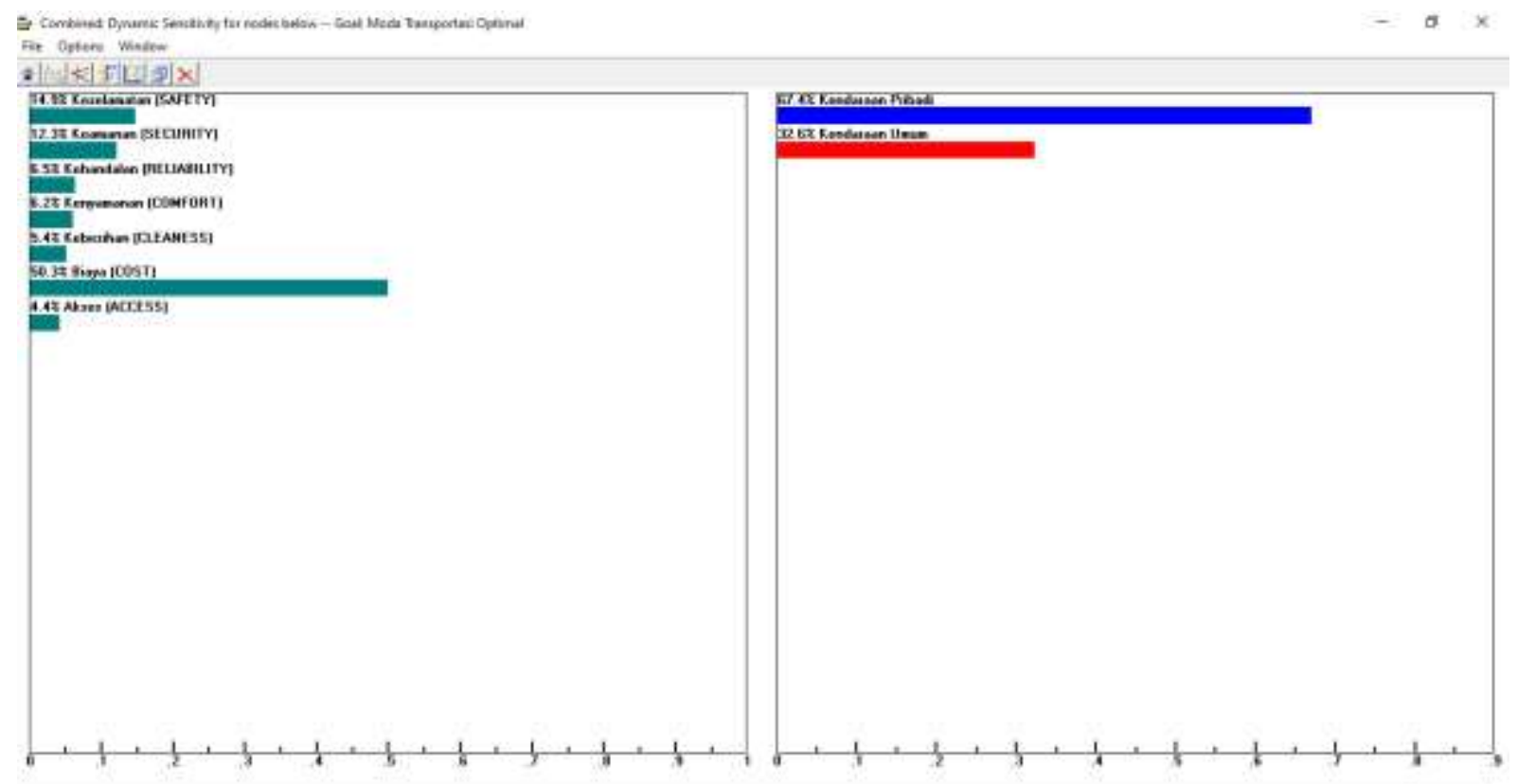

Gambar 4. Graffik sensitivitas antr faktor yang mempengaruhi 
Berdasarkan data yang telah dikumpulkan dan dianalisis, dapat ditemukan bahwa terdapat tujuh faktor yang mempengaruhi masyarakat dalam memilih moda transportasi dari bandara I Gusti Ngurah Rai ke Kota Denpasar adalah komponen keselamatan, keamanan, kehandalan, kenyamanan, kebersihan, biaya dan akses. Dalam melakukan perjalanan dari Bandara I Gusti Ngurah Rai ke Kota Denpasar, responden lebih memilih menggunakan kendaraan pribadi daripada kendaraan umum. Hal ini karena kendaraan pribadi menawarkan layanan tingkat tinggi seperti; kenyamanan, keselamatan, keamanan, keandalan, aksesibilitas, menghemat waktu perjalanan, dan biaya rendah. Di sisi lain, kendaraan umum tidak dapat memenuhi kebutuhan-kebutuhan tersebut dengan baik.

Orang-orang di Bali sebagian besar bergantung pada aspek keselamatan dan keamanan dalam memilih moda transportasi. Mereka menganggap bahwa kendaraan pribadi merupakan moda yang memberikan aman dan selamat dibandingkan dengan kendaraan umum. Di sisi lain, Masyarakat kemungkinan enggan menggunakan angkutan umum karena melihat faktor kehandalan, kenyamanan, dan kebersihan kendaraan umum cukup minim. Hal ini dapat dilihat dari kondisi angkutan umum yang ada di Bali yang rata-rata sudah berusia tua dan masyarakat melihat sebagian besar angkutan umum kurang terawat dan pengemudi yang tidak dibekali dengan keterampilan yang baik. Selain itu faktor lain yang membuat masyarakat kurang berminat menggunakan angkutan umum adalah rute angkutan umum yang tidak dapat menjangkau seluruh wilayah dan menyebabkan masyarakat sulit mencapai tujuan.

Terkait usaha untuk menggaet pelaku perjalanan berpindah dari kendaraan pribadi ke kendaraan umum, dapat dilakukan dengan meningkatkan biaya operasional pengguna kendaraan pribadi dan menekan biaya operasional kendaraan umum. Penghapusan subsidi BBM untuk kendaraan pribadi dapat berdampak pada peningkatan biaya operasional kendaraan. Selain itu, peningkatan tarif parkir kendaraan pribadi di bandara pun dapat memberikan dampak terhadap beralihnya pelaku perjalanan menggunakan kendaraan umum. Peningkatan harga kendaraan pribadi dan penerapan pajak progresif juga dapat dilakukan karena masyarakat cenderung memiliki kendaraan karena harganya yang relative murah. Usaha lain yang dapat dilakukan untuk menarik pengguna kendaraan umum adalah peningkatan kualitas pelayanan mulai dari mengurangi waktu tempuh kendaraan umum (waktu dalam kendaraan, waktu menuju halte). Peningkatan aksesibilitas dengan menjangkau seluruh wilayah dan penambahan titik halte juga menjadi hal penting yang perlu dilakukan. Keandalan angkutan umum dapat ditingkatkan dengan memperpanjang jam operasional, penambahan fasilitas, dan perawatan secara rutin sehingga masyarakat berminat menggunakan angkutan umum.

\section{SIMPULAN}

Bali memiliki jumlah penduduk yang besar ditambah dengan tingginya jumlah kunjungan wisatawan ataupun kunjungan kerja kedinasan yang menggunakan moda transportasi udara. Jumlah intensitas penerbangan yang tinggi ini mempengaruhi penggunaan moda transportasi darat baik kendaraan umum maupun kendaraan pribadi yang meninggalkan Bandara I Gusti Ngurah Rai ke berbagai tujuan atau destinasi, termasuk perjalanan ke Kota Denpasar. Berdasarkan penelitian yang telah dilakukan, ditemukan bahwa masyarakat yang melakukan perjalanan dari bandara I Gusti Ngurah Rai ke Kota Denpasar di dominasi menggunakan kendaraan pribadi $(74,4 \%)$. Masyarakat merasa bahwa Kendaraan pribadi memiliki layanan berkualitas tinggi dan menjadi instrumen utama dalam perjalanan. Sementara itu, kualitas pelayanan kendaran umum dirasa masih kurang sehingga masyarakat enggan memilih kendaraan umum sebagai moda transportasi yang digunakan $(25,6 \%)$. 
Berdasarkan penelitian ini, terdapat beberapa faktor yang mempengaruhi orang untuk menggunakan moda transportasi tertentu yakni keselamatan, keamanan, kehandalan, kenyamanan, kebersihan, biaya dan akses. Berdasarkan penilaian yang dilakukan responden, didapatkan hasil bahwa keselamatan $(28,3 \%)$ menjadi faktor utama dalam pemilihan moda transportasi. Selanjutnya faktor keamanan (23,3\%), kehandalan (12,3\%), kenyamanan $(11,7 \%)$, kebersihan $(10,2 \%)$, aksesibilitas $(8,4 \%)$, dan biaya $(5,8 \%)$.

\section{DAFTAR PUSTAKA}

Peraturan Menteri Perhubungan No. PM 118 Tahun 2018 Tentang Penyelenggaraan Angkutan Sewa Khusus.

Peraturan Menteri Perhubungan No. PM 12 Tahun 2019 Tentang Pelindungan Keselamatan Pengguna Sepeda Motor yang Digunakan untuk Kepentingan Masyarakat.

Farida. Achmad Tarmizi, \& Yogi November, Farida., 2016, Analisis Pengaruh Bauran Pemasaran 7P Terhadap Kepuasan Pelanggan Pengguna Gojek Online, Jurnal Riset Manajemen dan Bisnis Vol. 1, No. 1: 31-40

Indriany. Alvin Widyantoro, \& Indra Wangsa, Sylvia, 2019, Analisis Pemilihan Moda dengan Model Multinominal Logit untuk Perjalanan Kerja dari Kota Tangerang Selatan-DKI Jakarta, Portal. Jurnal Teknik Sipil. Vol. 1. No.1: 24-32.

Kamaluddin, Rustian, 2003, Ekonomi Transportasi, Ghalia Indonesia, Jakarta.

Minal dan Sekhar Ravi. Ch, 2014, Mode Choice Analysis: Data, The Models, and Future Ahead, International Journal For Traffic And Transport Engineering, 4, (3): 269285Miro. Fidel, 2005, Perencanaan Transportasi, Erlangga, Jakarta.

Nasution, M.N. 2008. Manajemen Transportasi. Edisi Ketiga. Bogor: Ghalia Indonesia

Saaty, Thomas L., 2008, Decision Making With The Analytical Hierarchy Process. Int. J. Services Sciences. Volume 1, No. 1, 83-98.

Salim. Abbas, 2000, Manajemen Transportasi, Ghalia Indonesia, Jakarta.

Saputra. Renni Anggraini, \& M. Isya., Rahmad, 2017, Analisa Faktor-Faktor yang Mempengaruhi Pemilihan Moda Menuju Tempat Kerja Menggunakan Metode Analytic Hierarchy Process, Jurnal Teknik Sipil Universitas Syiah Kuala: 199-218

Soesilo. N. I., 1999, Ekonomi Perencanaan dan Manajemen Kota, Megister Perencanaan dan Kebijakan Publik Universitas Indonesia, Jakarta.

Suyatno. Mustafid dan Sugirato, Aris, 2011, Rancang Bangun sistem Pendukung Keputusan untuk Pemilihan Gagasan Dengan Metode Analytical Hierarchy Process (AHP), Universitas Diponegoro, Semarang

Tamin. Ofyar Z, 2000, Perencanaan dan Pemodelan Transportasi, Institut Teknologi Bandung, Bandung

Wijaya. Andika, 2016, Aspek Hukum Bisnis Transportasi Jalan Online, Sinar Grafika, Jakarta. 